\title{
A Facile Approach to the Synthesis of 3-Acylisoxazole Derivatives with Reusable Solid Acid Catalysts
}

\author{
Ken-ichi Itoh*a (iD) \\ Mamiko Hayakawab \\ Rina Abe $^{\text {b }}$ \\ Shinji Takahashib \\ Kenta Hasegawab \\ Tadashi Aoyamab \\ a Department of Liberal Arts and Science, College of Science and \\ Technology, Nihon University, 7-24-1, Narashinodai, Funabashi-shi, \\ Chiba 274-8501, Japan \\ itou.kennichi@nihon-u.ac.jp \\ ${ }^{b}$ Department of Material and Applied Chemistry, College of Science \\ and Technology, Nihon University, Kanda Surugadai, Chiyoda-ku, \\ Tokyo 101-8308, Japan
}

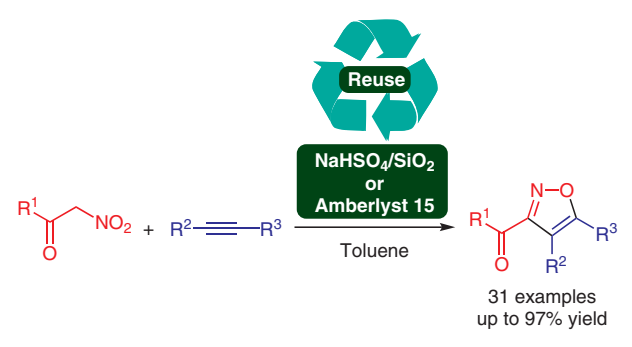

ence of silica gel-supported polyphosphoric acid (PPA/SiO $\left.{ }_{2}\right){ }^{7} \mathrm{~N}$-Alkoxyacyimidoyl halides were synthesized by the reaction of alkyl halides with nitrile oxides in the presence of $\mathrm{NaHSO}_{4} / \mathrm{SiO}_{2}{ }^{8}$ (Scheme 1a). Among the products, isoxazole and related 4,5-dihydroisoxazole (isoxazoline) derivatives as five-membered nitrogen-containing heterocycles are useful organic compounds.
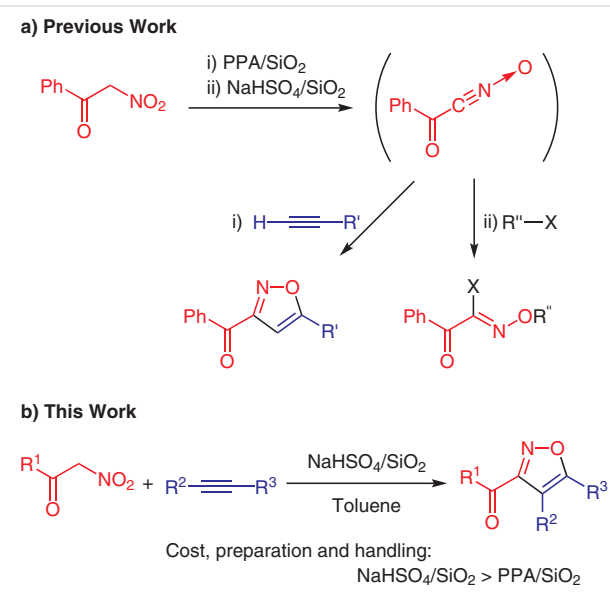

Scheme 1 A facile approach to the synthesis of isoxazole derivatives

The isoxazole ring units are a key structure in many of natural products or biologically and pharmaceutically active compounds ${ }^{9}$ (Figure 1), such as muscimol [3-hydroxy5-aminomethylisoxazole, $\gamma$-aminobutyric acid-A receptor $\left(\mathrm{GABA}_{\mathrm{A}}\right)$ agonist], ${ }^{10}$ and ibotenic acid [ $\alpha$-amino-3-hydroxy5-isoxazoleacetic acid, $N$-methyl-D-aspartate receptor (NMDA) agonist], ${ }^{11}$ or isocarboxazid [1-benzyl-2-(5-methyl-3-isoxazolylcarbonyl)hydrazine, monoamine oxidase inhibitors (MAOIs)], ${ }^{12}$ leflunomide [5-methyl- $N$-[4-(trifluoromethyl)phenyl]isoxazole-4-carboxamide, an immunosuppressive agents for rheumatoid arthritis $\},{ }^{13}$ and valdecoxib 
[4-(5-methyl-3-phenyl-4-isoxazolyl)benzenesulfoamide, cyclooxygenase-2 inhibitor]. ${ }^{14}$ Nitrile oxides are versatile intermediates prepared from aldoximes or nitroalkanes, affording isoxazole or isoxazoline derivatives by intermolecular [3+2] cycloaddition with dipolarophiles (alkynes or alkenes). ${ }^{15}$

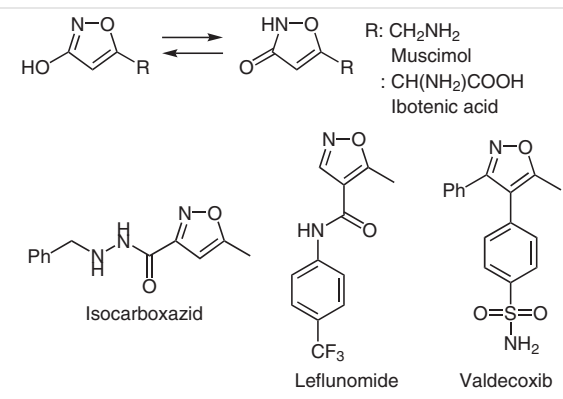

Figure 1 Biologically and pharmaceutically active isoxazoles

The heterocycles isoxazoles and isoxazolines are building blocks and available synthons in synthetic chemistry, and they can be converted into $\beta$-enamino ketones (from isoxazoles), ${ }^{16} \beta$-hydroxy ketones, or $\gamma$-amino alcohols (from isoxazolines) ${ }^{17}$ via the reductive ring cleavage of the $\mathrm{N}-\mathrm{O}$ heterocyclic bond. Concerning the synthesis of isoxazole derivatives from $\alpha$-nitro ketones as substrate, the corresponding nitrile oxides are prepared by the action of strong acid (sulfuric acid or $p$-toluenesulfonic acid) ${ }^{18}$ or base [1,4diazabicyclo[2.2.2] octane (DABCO) or copper(II) acetate/ $\mathrm{N}$-methylpiperidine (NMP)] on $\alpha$-nitro ketones. ${ }^{19}$ In this paper, we report on the facile synthesis of 3-acylisoxazoles ${ }^{20}$ from $\alpha$-nitro ketones and alkynes in the presence of $\mathrm{NaHSO}_{4} / \mathrm{SiO}_{2}$ (Scheme 1b). The use of $\mathrm{NaHSO}_{4} / \mathrm{SiO}_{2}$ is more excellent due to the low cost, preparation and handling (viscosity, calculation of the equivalent, and so on) compared with $\mathrm{PPA} / \mathrm{SiO}_{2}$. In addition, we would like to report the convenient synthetic method for isoxazole derivatives using Amberlyst 15 as a solid acid catalyst. Amberlyst 15, based on styrene-divinylbenzene polymer including a sulfo group, is a strong acidic catalyst in several organic reactions. ${ }^{21}$ Also, we have investigated the reusability of these catalysts in the present synthetic methods.

At first, the reaction of benzoylnitromethane (1a) and 1-octyne (2a) in the presence of $\mathrm{NaHSO}_{4} / \mathrm{SiO}_{2}$ was performed in toluene under reflux. The results in the amount of catalyst used are summarized in Table 1.

Since the reaction using $\mathrm{NaHSO}_{4} / \mathrm{SiO}_{2}(0.25 \mathrm{~g}, 2.1 \mathrm{mmol}$ $\mathrm{g}^{-1}$ ) gave 3-benzoyl-5-hexylisoxazole (3aa) in the highest yield (Table 1, entry 4 ), this condition was considered as the optimum.

This synthetic method is a heterogeneous reaction, and the separation of $\mathrm{NaHSO}_{4} / \mathrm{SiO}_{2}$ from the reaction mixture by filtration is simple. The recovered catalyst is reused in the next reaction after washing and drying. Therefore, we attempted the recycling reaction of $\mathrm{NaHSO}_{4} / \mathrm{SiO}_{2}$ (Table 2).
Table 1 Effect of the Amount of Catalyst on the Synthesis of 3aa

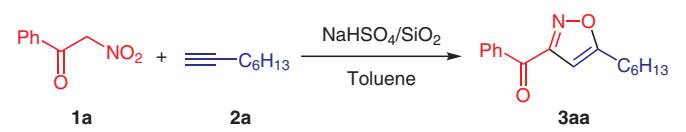

\begin{tabular}{lll}
\hline Entry & Amount $(\mathrm{g})$ of $\mathrm{NaHSO}_{4} / \mathrm{SiO}_{2}$ & Yield $(\%)^{\mathrm{b}}$ of 3aa \\
\hline 1 & 0.025 & $53, \mathbf{1 a}(45)^{\mathrm{c}}$ \\
2 & 0.050 & $73, \mathbf{1 a}(18)^{\mathrm{c}}$ \\
3 & 0.075 & 86 \\
4 & 0.25 & 89 \\
\hline
\end{tabular}

a Reaction conditions: 1 a $(0.50 \mathrm{mmol}), \mathbf{2 a}(0.60 \mathrm{mmol}), \mathrm{NaHSO}_{4} / \mathrm{SiO}_{2}$ $\left(2.1 \mathrm{mmol} \mathrm{g}^{-1}\right)$ in toluene $(5.0 \mathrm{~mL})$ under reflux for $6 \mathrm{~h}$.

${ }^{\mathrm{b}}$ The yields are based on $\mathbf{1 a}$ as determined by GLC.

' Yield of recovered $\mathbf{1 a .}$

Table 2 The Reusability of Recovered Catalyst on the Reaction of 1a and $2 a^{a}$

\begin{tabular}{lll}
\hline Entry & Number of uses & Yield $(\%)^{\mathrm{b}}$ of 3aa \\
\hline 1 & 1 & 89 \\
2 & 2 & 97 \\
3 & 3 & 99 \\
4 & 4 & 91 \\
5 & 5 & 98 \\
6 & 6 & 89 \\
7 & 7 & 88 \\
8 & 8 & $79, \mathbf{1 a}(14)^{\mathrm{c}}$ \\
9 & 9 & $78, \mathbf{1 a}(8)^{\mathrm{c}}$ \\
10 & 10 & $82, \mathbf{1 a}(16)^{\mathrm{c}}$ \\
\hline
\end{tabular}

a Reaction conditions: $1 \mathrm{a}(0.50 \mathrm{mmol}), 2 \mathrm{2a}(0.60 \mathrm{mmol}), \mathrm{NaHSO}_{4} / \mathrm{SiO}_{2}$

$\left(0.25 \mathrm{~g}, 2.1 \mathrm{mmol} \mathrm{g}^{-1}\right)$ in toluene $(5.0 \mathrm{~mL})$ under reflux for $6 \mathrm{~h}$.

$\mathrm{b}$ The yields are based on $1 \mathrm{a}$ as determined by GLC.

c Yield of recovered 1a.

From the results, it can be seen that this catalyst was recycled ten times (Table 2, entries 1-10), and 3aa was obtained in sufficient yield.

Also, the previous several reports indicated that the transformation of 1a to 3aa using acidic solid-supported reagents proceeded through the corresponding nitrile oxide, and the nitrile oxide was dimerized into the corresponding furoxan $\mathbf{4 a}$. Then, we tested the reaction of $\mathbf{1 a}$ in the presence of $\mathrm{NaHSO}_{4} / \mathrm{SiO}_{2}$ to confirm the reaction pathway (Scheme 2). When the reaction of $\mathbf{1 a}(0.50 \mathrm{mmol})$ was conducted in the presence of $\mathrm{NaHSO}_{4} / \mathrm{SiO}_{2}\left(0.25 \mathrm{~g}, 2.1 \mathrm{mmol} \mathrm{g}{ }^{-1}\right)$ in toluene $(5.0 \mathrm{~mL})$ under reflux for $6 \mathrm{~h}$, the corresponding furoxan $\mathbf{4 a}$ was formed in $11 \%$ isolated yield via dimerization of nitrile oxide formed by dehydration from $\mathbf{1 a}$.

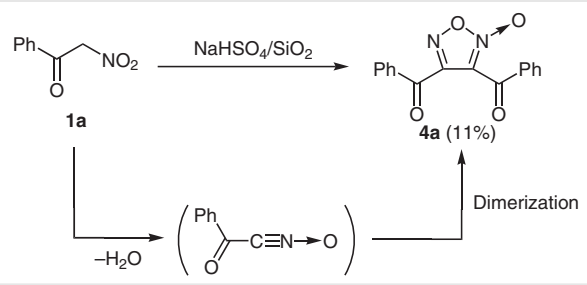

Scheme 2 Formation of furoxan 4 a from 1 a 
Then, the reaction of $\mathbf{1 a}$ with several alkynes $\mathbf{2}$ in the presence of $\mathrm{NaHSO}_{4} / \mathrm{SiO}_{2}$ was carried out (Table 3). In the reaction using terminal alkynes (Table 3, entries 1-13), 5substituted 3-benzoylisoxazoles were obtained in good yields expect from ethynylbenzene (21). The reaction using $\mathbf{2 1}$ afforded a low yield of 3al (36\%, entry 11). Besides, in the case of internal alkynes, 4,5-disubstituted 3-benzoylisoxazoles were obtained in moderately yields (entries 14 and 15).

Table 3 Reaction of $\mathbf{1 a}$ and Alkynes $\mathbf{2}$ in the Presence of $\mathrm{NaHSO}_{4} / \mathrm{SiO}_{2}{ }^{\mathrm{a}}$

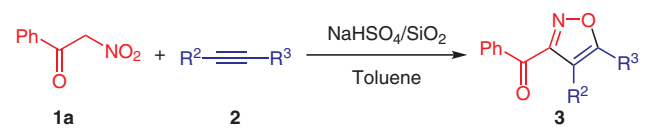

\begin{tabular}{|c|c|c|}
\hline Entry & Alkyne 2 & $\begin{array}{l}\text { Product } 3 \\
\text { Yield (\%) }\end{array}$ \\
\hline 1 & 2b $\left(R^{2}=H, R^{3}=C_{3} H_{7}\right)$ & $3 a b(86)$ \\
\hline 2 & $2 c\left(R^{2}=H, R^{3}=C_{4} H_{9}\right)$ & $3 a c(80)$ \\
\hline 3 & $2 \mathbf{d}\left(\mathrm{R}^{2}=\mathrm{H}, \mathrm{R}^{3}=\mathrm{C}_{5} \mathrm{H}_{11}\right)$ & 3ad (84) \\
\hline 4 & $2 e\left(R^{2}=H, R^{3}=C_{7} H_{15}\right)$ & 3ae (84) \\
\hline 5 & $2 \mathbf{f}\left(\mathrm{R}^{2}=\mathrm{H}, \mathrm{R}^{3}=\mathrm{C}_{8} \mathrm{H}_{17}\right)$ & 3af (92) \\
\hline 6 & $2 \mathbf{g}\left(\mathrm{R}^{2}=\mathrm{H}, \mathrm{R}^{3}=\mathrm{CH}_{2} \mathrm{Cl}\right)$ & $3 a g(82)$ \\
\hline 7 & $2 \mathrm{~h}\left(\mathrm{R}^{2}=\mathrm{H}, \mathrm{R}^{3}=\mathrm{CH}_{2} \mathrm{Br}\right)$ & $3 a h(93)$ \\
\hline 8 & $2 \mathbf{i}\left(R^{2}=H, R^{3}=C H M e_{2}\right)$ & 3ai (73) \\
\hline 9 & $2 \mathbf{j}\left(\mathrm{R}^{2}=\mathrm{H}, \mathrm{R}^{3}=\mathrm{CMe}_{3}\right)$ & 3aj (66) \\
\hline 10 & $2 \mathbf{k}\left(R^{2}=H, R^{3}=\mathrm{SiMe}_{3}\right)$ & 3ak (97) \\
\hline 11 & $\mathbf{2 l}\left(\mathrm{R}^{2}=\mathrm{H}, \mathrm{R}^{3}=\mathrm{Ph}\right)$ & $3 a l(36)$ \\
\hline 12 & $2 \mathbf{m}\left(\mathrm{R}^{2}=\mathrm{H}, \mathrm{R}^{3}=\mathrm{CO}_{2} \mathrm{Me}\right)$ & $\operatorname{3am}(90)$ \\
\hline 13 & $2 \mathbf{n}\left(R^{2}=H, R^{3}=\mathrm{CO}_{2} E t\right)$ & 3an (91) \\
\hline 14 & $20\left(R^{2}=R^{3}=C_{2} M e\right)$ & $3 a o(66)$ \\
\hline 15 & $2 p\left(R^{2}=R^{3}=C_{2} E t\right)$ & $3 a p(69)$ \\
\hline
\end{tabular}

a Reaction conditions: $1 \mathrm{a}(0.50 \mathrm{mmol}), 2$ (0.60 mmol), $\mathrm{NaHSO}_{4} / \mathrm{SiO}_{2}$

$\left(0.25 \mathrm{~g}, 2.1 \mathrm{mmol} \mathrm{g}^{-1}\right)$ in toluene $(5.0 \mathrm{~mL})$ under reflux for $6 \mathrm{~h}$.

${ }^{\mathrm{b}}$ Isolated yield based on $\mathbf{1 a}$.

In addition, we tested the reaction using 1-octene (5a) as one example about the use of alkenes to compare with the synthetic method using $\mathrm{PPA} / \mathrm{SiO}_{2}{ }^{7}$ When 1a $(0.50$ $\mathrm{mmol}$ ) was reacted with 1 -octene $(\mathbf{5 a} ; 0.60 \mathrm{mmol})$ in the presence of $\mathrm{NaHSO}_{4} / \mathrm{SiO}_{2}\left(0.25 \mathrm{~g}, 2.1 \mathrm{mmol} \mathrm{g}^{-1}\right)$ in toluene $(5 \mathrm{~mL})$ under reflux for 6 hours, the corresponding 3-benzoyl-5-hexyl-4,5-dihydroisoxazole (6aa) was obtained in $89 \%$ isolated yield (Scheme 3 ).

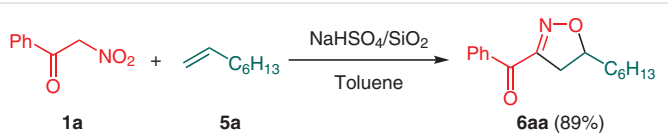

Scheme 3 Reaction of $1 \mathbf{a}$ and $\mathbf{5 a}$ in the presence of $\mathrm{NaHSO}_{4} / \mathrm{SiO}_{2}$

Also, the reaction of $\alpha$-nitro ketones $\mathbf{1 b}$-e with alkynes 2 in the presence of $\mathrm{NaHSO}_{4} / \mathrm{SiO}_{2}$ was carried out (Table 4).

In the case of 1 containing aromatic ring, 3-acylisoxazoles were obtained in good yields (Table 4, entries 1, 2, 5, 6, 9 , and 10). However, the reaction of $\mathbf{1 d}-\mathbf{e}$ substituted with alkyl group gave the corresponding isoxazoles in moderate yields (entries $3,4,7,8$, and 11 ).
Table 4 The Reaction of $\alpha$-Nitro Ketones $\mathbf{1 b}$-e and Alkynes $\mathbf{2}$ in the Presence of $\mathrm{NaHSO}_{4} / \mathrm{SiO}_{2}{ }^{\mathrm{a}}$

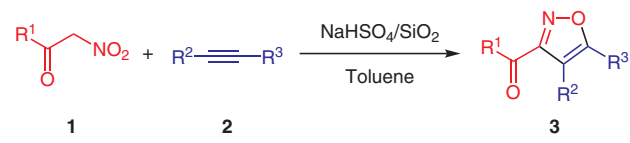

\begin{tabular}{|c|c|c|c|}
\hline Entry & $\alpha$-Nitro ketone 1 & Alkyne 2 & $\begin{array}{l}\text { Product } 3 \text { Yield } \\
(\%)^{\mathrm{b}}\end{array}$ \\
\hline
\end{tabular}

\begin{tabular}{|c|c|c|c|}
\hline 1 & $\mathbf{1 b}, \mathrm{R}^{1}=4-\mathrm{MeC}_{6} \mathrm{H}_{4}$ & $2 a$ & 3ba (96) \\
\hline 2 & 1c, $\mathrm{R}^{1}=$ 2-Thienyl & $2 a$ & $3 c a(81)$ \\
\hline 3 & $\mathbf{1 d}, \mathrm{R}^{1}=\mathrm{Et}$ & $2 a$ & 3da (75) \\
\hline 4 & 1e, $\mathrm{R}^{1}=\mathrm{C}_{10} \mathrm{H}_{21}$ & $2 a$ & 3ea (70) \\
\hline 5 & $1 \mathrm{~b}$ & $2 \mathrm{~h}$ & 3bh (91) \\
\hline 6 & 1c & $2 \mathrm{~h}$ & $3 c h(84)$ \\
\hline 7 & 1d & $2 \mathrm{~h}$ & 3dh (75) \\
\hline 8 & $1 \mathrm{e}$ & $2 \mathrm{~h}$ & 3eh (70) \\
\hline 9 & $1 b$ & $2 p$ & $3 b p(85)$ \\
\hline 10 & 1c & $2 p$ & 3 ср (68) \\
\hline 11 & $1 e$ & $2 p$ & $3 e p(61)$ \\
\hline
\end{tabular}

Among the $\alpha$-nitro ketones, the reaction of ethyl nitroacetate (1f; $\left.\mathrm{R}^{1}=\mathrm{OEt}\right)$ with $\mathbf{2 a}$ gave the corresponding isoxazole derivative 3 fa in low yield ( $27 \%$ yield, Table 5 , entry 1 ). However, the reaction using 0 -dichlorobenzene as solvent instead of toluene increased the yield of 3fa (entry 2), namely, it was necessary to use a higher temperature to transform 1f into the corresponding nitrile oxide. The results using other alkynes are shown in Table 5.

Table 5 Reaction of $\mathbf{1 f}$ with Alkynes $\mathbf{2}$ in the Presence of $\mathrm{NaHSO}_{4} / \mathrm{SiO}_{2}{ }^{\mathrm{a}}$

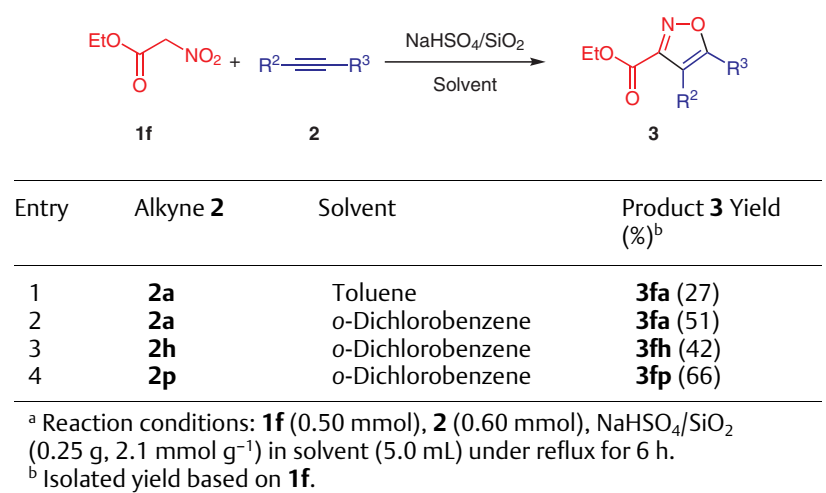

On the other hand, we also investigated using Amberlyst 15 to change the supported reagent in the synthesis of 3aa from 1a and 2a. We first examined the reaction using several solvents (Table 6 ), and it became clear that the use of toluene as solvent gave the highest yield compared with other solvents (Table 6, entry 5). 
Table 6 Effect of Solvent on the Reaction of $1 \mathbf{a}$ with $2 \mathbf{a}^{\mathrm{a}}$

\begin{tabular}{lll}
\hline Entry & Solvent & Yield (\%) of 3aa \\
\hline 1 & $\mathrm{MeOH}$ & Trace \\
2 & $\mathrm{H}_{2} \mathrm{O}$ & N.D. \\
3 & $\mathrm{CH}_{2} \mathrm{Cl}_{2}$ & 4 \\
4 & $\mathrm{MeCN}_{5}$ & 20 \\
5 & Toluene & 94 \\
6 & DMSO & 8 \\
7 & DMF & N.D. \\
\hline
\end{tabular}

a Reaction conditions: 1 a $(0.30 \mathrm{mmol})$, 2 a $(0.36 \mathrm{mmol})$, Amberlyst 15 $(0.030 \mathrm{~g})$ in solvent $(2.0 \mathrm{~mL})$ at $80^{\circ} \mathrm{C}$ for $12 \mathrm{~h}$.

${ }^{b} \mathrm{GLC}$ yield based on 1a. N.D.: Not detected.

Besides, we tried to the explore the optimized reaction conditions, and the results are shown in Table 7 . When the reaction of $\mathbf{1 a}$ and $\mathbf{2 a}$ in the presence of Amberlyst 15 $(0.020 \mathrm{~g})$ was carried out in toluene at $80^{\circ} \mathrm{C}$ for 9 hours, 3aa was obtained in high yield (99\%, Table 7 , entry 10$)$.

Table 7 Optimization of the Reaction Conditions Using 1a and 2a in the Presence of Amberlyst 15a

\begin{tabular}{lllll}
\hline Entry & Amberlyst $15(\mathrm{~g})$ & Temp $\left({ }^{\circ} \mathrm{C}\right)$ & Time $(\mathrm{h})$ & Yield $(\%)^{\mathrm{b}}$ of 3aa \\
\hline 1 & 0.005 & 80 & 12 & 50 \\
2 & 0.010 & 80 & 12 & 83 \\
3 & 0.020 & 80 & 12 & 90 \\
4 & 0.030 & 80 & 12 & 88 \\
5 & 0.020 & rt & 12 & Trace \\
6 & 0.020 & 60 & 12 & 75 \\
7 & 0.020 & reflux & 12 & 70 \\
8 & 0.020 & 80 & 3 & 90 \\
9 & 0.020 & 80 & 6 & 97 \\
10 & 0.020 & 80 & 9 & 99 \\
\hline
\end{tabular}

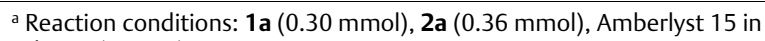
toluene $(2.0 \mathrm{~mL})$.

${ }^{\mathrm{b}} \mathrm{GLC}$ yield based on $\mathbf{1 a}$.

We then tested the recycling reaction using Amberlyst 15 (Table 8). After the reaction, Amberlyst 15 was recovered by filtration, and washed with methanol three times.

The typical advantage of Amberlyst 15 is the ability of its regeneration, in other words, the sulfo group was easily regenerated by treating with acid solution, especially with aqueous $\mathrm{HCl}\left(1 \mathrm{~mol} \mathrm{~L}^{-1}\right)$. The yields of 3aa and the amounts of recovered catalyst were decreased gradually in accordance with the number of uses (Table 8, entries 1-5). Then, the reaction using acid regenerated catalyst $\left(\mathrm{HCl} 1 \mathrm{~mol} \mathrm{~L}^{-1}\right)$ before the 6th reaction gave 3aa in improved yield (entries 5 and 6). However, since the amount of catalyst was decreased to $47 \%$ in the 7 th reaction, the yield of 3aa was lowered (entry 7). In the case of renewable reactions by aqueous $\mathrm{HCl}$ in every time, these trends have continued (entries 8-14). Mostly, the shape of purchased Amberlyst 15 has a spherical structure (Figure 2). Before the reaction Amberlyst 15 was steeped in and washed with methanol, continuously desiccated under reduced pressure, but the shape was hardly changed. Also, when the number of uses were
Table 8 The Reusability of Recovered Catalyst by Filtration on the Reaction of $\mathbf{1 a}$ and $\mathbf{2} \mathbf{a}^{\mathrm{a}}$

\begin{tabular}{llll}
\hline Entry & Number of uses & Recovered catalyst $(\%)^{b}$ & Yield $(\%)^{c}$ of 3aa \\
\hline 1 & 1 & 100 & 89 \\
2 & 2 & 100 & 95 \\
3 & 3 & 100 & 81 \\
4 & 4 & 74 & 59 \\
5 & 5 & 67 & 51 \\
$6^{\text {d }}$ & 6 & 52 & 75 \\
7 & 7 & 47 & 63 \\
$8^{\text {d }}$ & 1 & 100 & 85 \\
$9^{\text {d }}$ & 2 & 95 & 89 \\
$10^{\text {d }}$ & 3 & 91 & 96 \\
$11^{\text {d }}$ & 4 & 69 & 83 \\
$12^{\text {d }}$ & 5 & 43 & 85 \\
$13^{\text {d }}$ & 6 & 38 & 71 \\
$14^{\text {d }}$ & 7 & 32 & 39 \\
\hline
\end{tabular}

a Reaction conditions: 1 a $(0.30 \mathrm{mmol}), 2 \mathrm{a}(0.36 \mathrm{mmol})$, Amberlyst 15

$(0.020 \mathrm{~g})$ in toluene $(2.0 \mathrm{~mL})$ at $80^{\circ} \mathrm{C}$ for $9 \mathrm{~h}$.

${ }^{b}$ Based on the amount of Amberlyst 15 at the first reaction.

${ }^{\circ} \mathrm{GLC}$ yield based on $\mathbf{1 a}$.

Recovered Amberlyst 15 was regenerated by $\mathrm{HCl}\left(1 \mathrm{~mol} \mathrm{~L}^{-1}\right)$.

increased, the recovery of catalyst would be difficult because it had decomposed into a fine powder. The surface of Amberlyst 15, which was kept as a spherical structure after the reaction, was gradually coarse as the number of reactions progress (Figure 2a,b). Therefore, we tried to improve the recovered method by using decantation instead of filtration to increase the recovered amount of catalyst (Table 9).
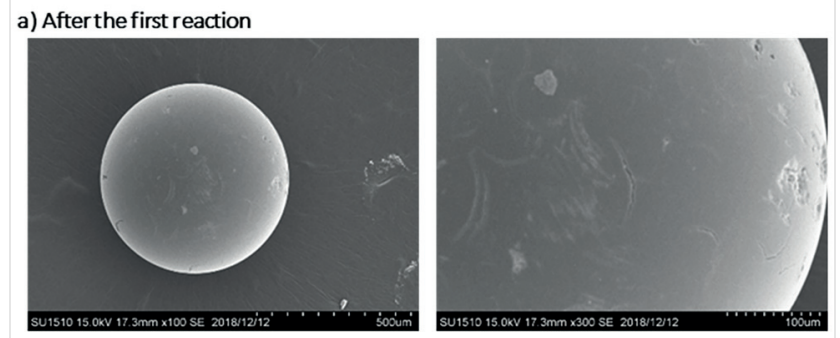

b) After the $7^{\text {th }}$ reaction
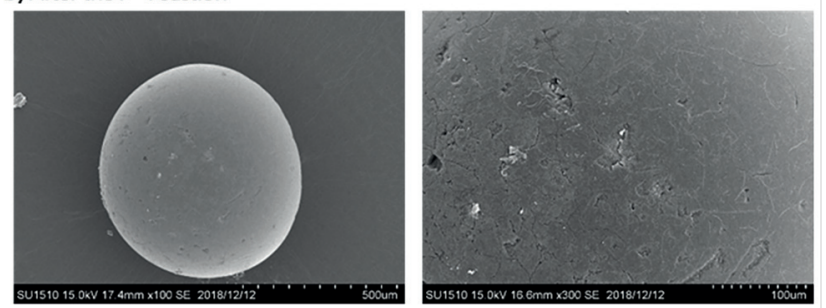

Figure 2 The SEM images of Amberlyst 15 (Left: whole, Right: enlargement)

In this method, the reaction mixture was collected from the vessel by decantation, and then Amberlyst 15 was steeped in and washed with methanol. Continuously, methanol in the vessel was removed by decantation. After this process was conducted three times, Amberlyst 15 was dried under decompression by evaporation. In the regeneration 
Table 9 The Reusability of Recovered Catalyst by Decantation ${ }^{\mathrm{a}}$

\begin{tabular}{llll}
\hline Entry & Number of uses & Recovered catalyst (\%) & Yield (\%) of 3aa \\
\hline 1 & 1 & 100 & 94 \\
2 & 2 & 100 & 96 \\
3 & 3 & 99 & 93 \\
4 & 4 & 97 & 88 \\
5 & 5 & 97 & 86 \\
\hline
\end{tabular}

a Reaction conditions: 1a (0.30 mmol), 2a (0.36 mmol), Amberlyst 15

$(0.020 \mathrm{~g})$ in toluene $(2.0 \mathrm{~mL})$ at $80^{\circ} \mathrm{C}$ for $9 \mathrm{~h}$.

${ }^{\mathrm{b}}$ Based on the amount of Amberlyst 15 at the first reaction.

${ }^{\mathrm{C}} \mathrm{GLC}$ yield based on $\mathbf{1 a}$.

section, aqueous $\mathrm{HCl}\left(1 \mathrm{~mol} \mathrm{~L} \mathrm{~L}^{-1}, 1.0 \mathrm{~mL}\right)$ was added to the vessel containing the catalyst, and this mixture was stirred for 0.5 hour. After the treatment, $\mathrm{HCl}$ solution was removed, and Amberlyst 15 was washed each with water and methanol three times. All the cleaning solvents were removed by decantation. Finally, Amberlyst 15 was dried under decompression by evaporation and used in the next reaction. From the results, the recovered amount of catalyst had been improved and 3aa was obtained in a satisfactory yield in the 5 th reuse of the reaction (Table 9 , entry 5 ).

Furthermore, the formation of $\mathbf{4 a}$ was confirmed in the reaction of $1 \mathbf{a}$ using Amberlyst 15 as with $\mathrm{NaHSO}_{4} / \mathrm{SiO}_{2}$.

Finally, the reaction of $\alpha$-nitro ketones $\mathbf{1}$ with alkynes $\mathbf{2}$ in the presence of Amberlyst 15 was carried out. These results are summarized in Table 10 . In all the reactions, the corresponding 3-acylisoxazoles were obtained, and then the similar tendency of product yield could also be seen concerning acid solid-supported reagent.

Table 10 The Reaction of $\alpha$-Nitro Ketones $\mathbf{1}$ and Alkynes $\mathbf{2}$ in the Presence of Amberlyst $15^{a}$

\begin{tabular}{|c|c|c|c|}
\hline Entry & $\begin{array}{l}\alpha \text {-Nitro ketone } \\
\mathbf{1}\end{array}$ & Alkyne 2 & $\begin{array}{l}\text { Product } 3 \\
\text { Yield }(\%)^{\mathrm{b}}\end{array}$ \\
\hline 1 & 1a & $2 \mathrm{~h}$ & 3ah (85) \\
\hline 2 & $1 a$ & 21 & $3 a l(40)$ \\
\hline 3 & 1a & $2 n$ & $3 a n(79)$ \\
\hline 4 & $1 a$ & $2 p$ & 3ap $(80,95 / 93 / 93 / 90)^{c}$ \\
\hline 5 & 1c & $2 a$ & 3ca $(82,97 / 91 / 98 / 96)^{c}$ \\
\hline 6 & 1c & $2 \mathrm{~h}$ & 3ch $(81)$ \\
\hline 7 & 1c & $2 p$ & $3 c p(64)$ \\
\hline \multicolumn{4}{|c|}{$\begin{array}{l}\text { a Reaction conditions: } \mathbf{1}(0.30 \mathrm{mmol}), \mathbf{2}(0.36 \mathrm{mmol}), \text { Amberlyst } 15 \\
(0.020 \mathrm{~g}) \text { in toluene }(2.0 \mathrm{~mL}) \text { at } 80^{\circ} \mathrm{C} \text { for } 9 \mathrm{~h} . \\
\mathrm{b} \text { Isolated yield based on } \mathbf{1} . \\
{ }^{\mathrm{C}} \mathrm{GLC} \text { yield based on } \mathbf{1} \text { in the recycling and regenerative reactions } \\
\text { (1 } \mathrm{st} / 2 \mathrm{nd} / 3 \mathrm{rd} / 4 \text { th reaction). }\end{array}$} \\
\hline
\end{tabular}

Moreover, in the synthesis of 3ap and 3ca, when the recycling reactions were performed at the 4 th time, the products were obtained in excellent yields (Table 10, entries 4 and 5).

Likewise, in the reaction using $\mathbf{1 a}$ and $\mathbf{2 1}$, it was found that acetophenone $\mathbf{7}$ was obtained as a by-product in $78 \%$ GLC yield based on $\mathbf{2 1}$. Therefore, we investigated the time course of this reaction (Table 11).
Table 11 The Time Course of Reaction Using $\mathbf{1} \mathbf{a}$ and $\mathbf{2 l}^{\mathrm{a}}$

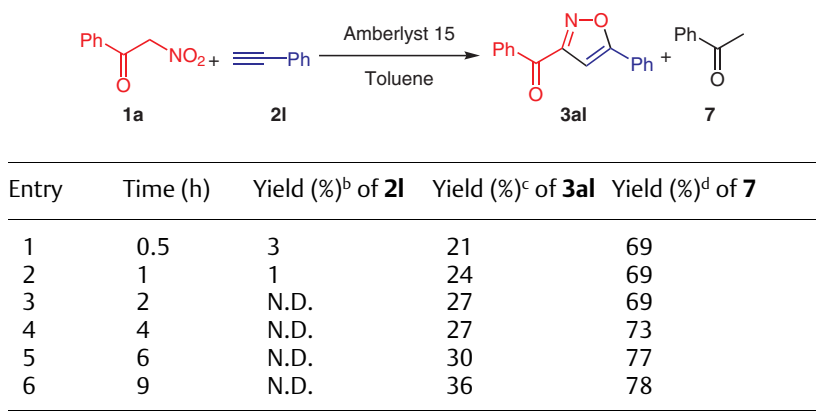

a Reaction conditions: 1a $(0.30 \mathrm{mmol}), \mathbf{2 l}$ ( $0.36 \mathrm{mmol})$, Amberlyst 15 $(0.020 \mathrm{~g})$ in toluene $(2.0 \mathrm{~mL})$ at $80^{\circ} \mathrm{C}$ for $9 \mathrm{~h}$.

${ }^{\mathrm{b}}$ GLC yield based on 2l. N.D.: Not detected.

' $G L C$ yield based on $\mathbf{1 a}$.

${ }^{\mathrm{d}} \mathrm{GLC}$ yield based on $\mathbf{2 l}$.

Since it was known that hydration of alkynes gave the corresponding carbonyl compounds under acidic condition, it seems that the formations of 3al via the cycloaddition and $\mathbf{7}$ via the hydration concertedly proceeded in this reaction (Scheme 4). From the results in the time course, it seems that the reaction rate of hydration is faster than cycloaddition because Amberlyst 15 directly react with 21. Besides, even in the reaction using $1 \mathbf{a}$ and $\mathbf{2 a}, 2$-octanone (8) was obtained via the hydration of $\mathbf{2 a}$ in 0.50 (reaction time: $1 \mathrm{~h}), 9.5$ ( $2 \mathrm{~h}$ ), 24 (4 h) and 26\% (6 h) GLC yields, respectively. From the results, since the hydration of $2 \mathbf{a}$ by Amberlyst $\mathbf{1 5}$ is slower than $\mathbf{2 1}$ in the reaction rate, 3aa was formed in high yield in the reaction of $\mathbf{1} \mathbf{a}$ and $\mathbf{2 a}$.

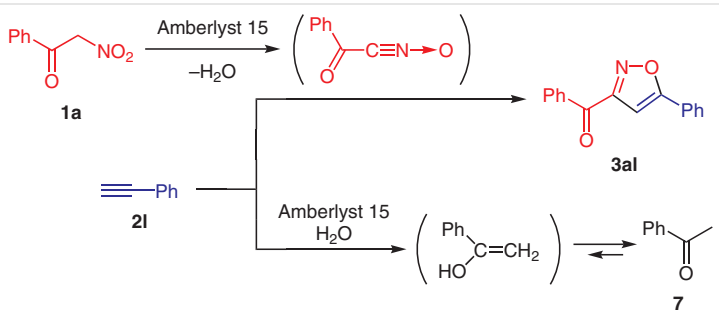

Scheme 4 Reaction mechanism for the formation of 3al and 7

In conclusion, we have proposed a facile and reusable synthetic method of 3-acylisoxazole derivatives using $\mathrm{NaHSO}_{4} / \mathrm{SiO}_{2}$, or Amberlyst 15 as solid acid catalyst. In the application of solid-supported reagent, isoxazole derivatives were obtained at a lower price and to make experimental procedure easier compared with the use of $\mathrm{PPA} / \mathrm{SiO}_{2}$. Also, the use of acidic ion-exchange resin afforded isoxazole derivatives in a small-scale, easy handling, and renewable reaction. These catalysts can be used for different purposes as required with the effective production of isoxazole derivatives. 
All reagents were purchased from commercial source. Melting points were determined on Büchi Melting Point B-540, or Mettler Toledo MP70 Melting Point System. NMR spectra were recorded on a JEOL ECX 400 spectrometer, TMS $(\delta=0)$ was used as an internal standard for ${ }^{1} \mathrm{H}$ NMR and $\mathrm{CDCl}_{3}(\delta=77.0)$ for ${ }^{13} \mathrm{C}$ NMR spectroscopy. IR spectra were recorded using a Jasco FT/IR 6100 spectrometer. Mass analyses were performed on a Xevo G2-5 QTof (Waters) or a JEOL GCMate spectrometer. GC analyses were performed using GC column (DB-1, $25 \mathrm{~m}$ ) equipped with a Shimazu GC-2014. Scanning electron microscope (SEM) of Amberlyst 15 was performed on a Hitachi SU-1510 SEM.

\section{$\mathrm{NaHSO}_{4} / \mathrm{SiO}_{2}$}

Silica gel $\left(\mathrm{SiO}_{2}\right.$, Wakogel $\left.\mathrm{C}-200,10 \mathrm{~g}\right)$ was added to a solution of $\mathrm{NaHSO}_{4} \cdot \mathrm{H}_{2} \mathrm{O}(4.14 \mathrm{~g}, 30 \mathrm{mmol})$ in distilled $\mathrm{H}_{2} \mathrm{O}$, and the mixture was stirred at rt for $0.5 \mathrm{~h} . \mathrm{H}_{2} \mathrm{O}$ was removed by rotary evaporator under reduced pressure, and the resulting reagent was dried in vacuo at 120 ${ }^{\circ} \mathrm{C} / 10$ Torr for $5 \mathrm{~h}$.

\section{3-Acylisoxazoles Using $\mathrm{NaHSO}_{4} / \mathrm{SiO}_{2}$; General Procedure}

A mixture of $\alpha$-nitro ketone $\mathbf{1}^{22}(0.50 \mathrm{mmol})$, alkyne $\mathbf{2}(0.60 \mathrm{mmol})$, and $\mathrm{NaHSO}_{4} / \mathrm{SiO}_{2}\left(0.25 \mathrm{~g}, 2.1 \mathrm{mmol} \mathrm{g}{ }^{-1}\right)$ was stirred in toluene (5.0 $\mathrm{mL}$ ) under reflux for $6 \mathrm{~h}$. After completion of the reaction, the mixture was filtered, and the recovered supported reagent was washed with small amounts of toluene and EtOAc. The solvent was removed from the filtrate by evaporation and the obtained crude product was purified by column chromatography (hexane/EtOAc). The GLC yield of 3acylisoxazole was determined using 2,7-dimethoxynaphthalene as an internal standard. In the recycling reaction, after the reaction, recovered $\mathrm{NaHSO}_{4} / \mathrm{SiO}_{2}$ was washed with toluene, and dried at $180^{\circ} \mathrm{C}$ for 2 $\mathrm{h}$; consecutively dried catalyst was used in the next reaction.

\section{3-Acylisoxazoles Using Amberlyst 15; General Procedure}

A mixture of $\alpha$-nitro ketone $\mathbf{1}^{22}(0.30 \mathrm{mmol})$, alkyne $\mathbf{2}(0.36 \mathrm{mmol})$, and Amberlyst $15(0.020 \mathrm{~g})$ was stirred in toluene $(2.0 \mathrm{~mL})$ at $80^{\circ} \mathrm{C}$ for $9 \mathrm{~h}$. After completion of the reaction, the mixture was filtered, and the recovered Amberlyst 15 was washed with $\mathrm{MeOH}$. The solvent was removed from the filtrate by evaporation and the obtained crude product was purified by column chromatography (hexane/EtOAc). The GLC yield of 3-acylisoxazoles were obtained using $n$-dodecane as an internal standard. In the recycling reaction, after the reaction, Amberlyst 15 was washed and regenerated to comply with the procedure.

The analytical and spectral data of newly prepared 3-acylisoxazoles are listed below.

\section{3-Benzoyl-5-heptylisoxazole (3ae)}

White solid; yield: $0.114 \mathrm{~g}(84 \%) ; \mathrm{mp} 42-43^{\circ} \mathrm{C}$.

IR (neat): 3131, 2951, 2927, 2850, 1657, $1593 \mathrm{~cm}^{-1}$.

${ }^{1} \mathrm{H} \mathrm{NMR}\left(\mathrm{CDCl}_{3}, 400 \mathrm{MHz}\right): \delta=0.89(\mathrm{t}, J=6.8 \mathrm{~Hz}, 3 \mathrm{H}), 1.27-1.42(\mathrm{~m}, 8$ $\mathrm{H}), 1.76$ (quint, $J=7.6 \mathrm{~Hz}, 2 \mathrm{H}$ ), $2.84(\mathrm{t}, J=7.6 \mathrm{~Hz}, 2 \mathrm{H}), 6.52(\mathrm{~s}, 1 \mathrm{H})$, 7.26-7.53 (m, $2 \mathrm{H}$ ), 7.61-7.65 ( $\mathrm{m}, 1 \mathrm{H}$ ), 8.28-8.31 ( $\mathrm{m}, 2 \mathrm{H}$ ).

${ }^{13} \mathrm{C} \mathrm{NMR}\left(\mathrm{CDCl}_{3}, 100 \mathrm{MHz}\right): \delta=14.0,22.6,26.6,27.4,28.8,29.0,31.6$, 101.6, 128.5, 130.6, 133.9, 135.8, 161.8, 174.7, 186.1.

HRMS (TOF-Cl): $m / z\left[\mathrm{MH}^{+}\right]$calcd for $\mathrm{C}_{17} \mathrm{H}_{22} \mathrm{NO}_{2}$ : 272.1650; found: 272.1626 .

\section{3-Benzoyl-5-octylisoxazole (3af)}

Pale-yellow oil; yield: $0.131 \mathrm{~g}$ (92\%).
IR (neat): 2927, 2855, 1662, $1597 \mathrm{~cm}^{-1}$.

${ }^{1} \mathrm{H} \mathrm{NMR}\left(\mathrm{CDCl}_{3}, 400 \mathrm{MHz}\right): \delta=0.89(\mathrm{t}, J=7.2 \mathrm{~Hz}, 3 \mathrm{H}), 1.28-1.42(\mathrm{~m}$, $10 \mathrm{H}$ ), 1.75 (quint, $J=7.2 \mathrm{~Hz}, 2 \mathrm{H}), 2.84(\mathrm{t}, J=7.6 \mathrm{~Hz}, 2 \mathrm{H}), 6.52(\mathrm{~s}, 1 \mathrm{H})$, 7.49-7.54 (m, $2 \mathrm{H}), 7.61-7.66(\mathrm{~m}, 1 \mathrm{H}), 8.28-8.31(\mathrm{~m}, 2 \mathrm{H})$.

${ }^{13} \mathrm{C} \mathrm{NMR}\left(\mathrm{CDCl}_{3}, 100 \mathrm{MHz}\right): \delta=14.1,22.6,26.6,27.4,29.0,29.1,29.1$, $31.8,101.6,128.5,130.6,133.8,135.9,161.8,174.7,186.1$.

HRMS (TOF-Cl): $m / z$ [MH'] calcd for $\mathrm{C}_{18} \mathrm{H}_{24} \mathrm{NO}_{2}$ : 286.1807; found: 286.1769.

\section{3-Benzoyl-4,5-diethoxycarbonylisoxazole (3ap)}

White solid; yield: $0.109 \mathrm{~g}(69 \%) ; \mathrm{mp} 44-45^{\circ} \mathrm{C}$.

IR (neat): 2986, 2936, 1747, 1732, 1669, $1597 \mathrm{~cm}^{-1}$.

${ }^{1} \mathrm{H} \mathrm{NMR}\left(\mathrm{CDCl}_{3}, 400 \mathrm{MHz}\right): \delta=1.29(\mathrm{t}, J=7.2 \mathrm{~Hz}, 3 \mathrm{H}), 1.44(\mathrm{t}, J=7.2$ $\mathrm{Hz}, 3 \mathrm{H}), 4.37$ (q, J = 7.2 Hz, $2 \mathrm{H}), 4.50(\mathrm{q}, J=7.2 \mathrm{~Hz}, 2 \mathrm{H}), 7.52-7.56(\mathrm{~m}$, $2 \mathrm{H}), 7.66-7.71(\mathrm{~m}, 1 \mathrm{H}), 8.15-8.18(\mathrm{~m}, 2 \mathrm{H})$.

${ }^{13} \mathrm{C}$ NMR $\left(\mathrm{CDCl}_{3}, 100 \mathrm{MHz}\right): \delta=13.8,14.0,62.5,63.2,117.6,128.8$, $130.5,134.8,134.9,155.8,159.3,159.7,159.9,183.9$.

HRMS (TOF-Cl): $m / z$ [MH'] calcd for $\mathrm{C}_{16} \mathrm{H}_{16} \mathrm{NO}_{6}$ : 318.0977; found: 318.0949 .

\section{3-(4-Methylbenzoyl)-5-bromomethylisoxazole (3bh)}

White solid; yield: $0.127 \mathrm{~g}(91 \%) ; \mathrm{mp} 76-78^{\circ} \mathrm{C}$.

IR (neat): 3137, 1642, 1597, 1170, 889, $754 \mathrm{~cm}^{-1}$.

${ }^{1} \mathrm{H} \mathrm{NMR}\left(\mathrm{CDCl}_{3}, 400 \mathrm{MHz}\right): \delta=2.45(\mathrm{~s}, 3 \mathrm{H}), 4.55(\mathrm{~s}, 2 \mathrm{H}), 6.84(\mathrm{~s}, 1 \mathrm{H})$, 7.32-7.34 (m, $2 \mathrm{H}), 8.20-8.22(\mathrm{~m}, 2 \mathrm{H})$.

${ }^{13} \mathrm{C} \mathrm{NMR}\left(\mathrm{CDCl}_{3}, 100 \mathrm{MHz}\right): \delta=18.0,21.8,104.7,129.4,130.8,132.9$, 145.4, 162.2, 168.2, 184.7 .

HRMS (TOF-Cl): $m / z$ [MH'] calcd for $\mathrm{C}_{12} \mathrm{H}_{11} \mathrm{BrNO}_{2}$ : 279.9973; found: 279.9975 .

\section{3-(4-Methylbenzoyl)-4,5-diethoxycarbonylisoxazole (3bp)}

Pale yellow oil; yield: $0.141 \mathrm{~g}(85 \%)$

IR (neat): 2992, 1738, 1279, 1181, 1092, 1014, $899 \mathrm{~cm}^{-1}$.

${ }^{1} \mathrm{H} \mathrm{NMR}\left(\mathrm{CDCl}_{3}, 400 \mathrm{MHz}\right): \delta=1.30(\mathrm{t}, J=7.2 \mathrm{~Hz}, 3 \mathrm{H}), 1.44(\mathrm{t}, J=7.2$ $\mathrm{Hz}, 3 \mathrm{H}), 2.46$ (s, $3 \mathrm{H}), 4.37$ (q, J = 7.2 Hz, $2 \mathrm{H}), 4.49$ (q, J = 7.6 Hz, $2 \mathrm{H}$ ), 7.32-7.34 (m, $2 \mathrm{H}), 8.05-8.08$ ( $\mathrm{m}, 2 \mathrm{H}$ ).

${ }^{13} \mathrm{C}$ NMR $\left(\mathrm{CDCl}_{3}, 100 \mathrm{MHz}\right): \delta=13.8,14.0,21.9,62.5,63.2,117.6$, 129.6, 130.6, 132.5, 146.1, 155.5, 159.1, 159.8, 160.0, 183.4.

HRMS (TOF-Cl): $m / z\left[\mathrm{MH}^{+}\right]$calcd for $\mathrm{C}_{17} \mathrm{H}_{18} \mathrm{NO}_{6}$ : 332.1134; found: 332.1128 .

\section{3-(2-Thienylcarbonyl)-5-bromomethylisoxazole (3ch)}

White solid; yield: $0.114 \mathrm{~g}(84 \%) ; \mathrm{mp} 78^{\circ} \mathrm{C}$.

IR (neat): $3035,1628,1396,1220,859,809,723 \mathrm{~cm}^{-1}$.

${ }^{1} \mathrm{H}$ NMR $\left(\mathrm{CDCl}_{3}, 400 \mathrm{MHz}\right): \delta=4.54(\mathrm{~s}, 2 \mathrm{H}), 6.85(\mathrm{~s}, 1 \mathrm{H}), 7.21-7.24$ ( $\mathrm{m}, 1 \mathrm{H}), 7.81-7.82(\mathrm{~m}, 1 \mathrm{H}), 8.45-8.46(\mathrm{~m}, 1 \mathrm{H})$.

${ }^{13} \mathrm{C} \mathrm{NMR}\left(\mathrm{CDCl}_{3}, 100 \mathrm{MHz}\right): \delta=17.9,104.2,128.7,136.3,136.8,141.3$, 161.9, 168.5, 176.4 .

HRMS (TOF-Cl): $m / z$ [MH'] calcd for $\mathrm{C}_{9} \mathrm{H}_{7} \mathrm{BrNO}_{2} \mathrm{~S}: 271.9380$; found: 271.9379 .

\section{3-Propanoyl-5-hexylisoxazole (3da)}

Pale-yellow oil; yield: $0.078 \mathrm{~g}$ (75\%).

IR (neat): 2930, 2864, 1704, 1451, $921 \mathrm{~cm}^{-1}$. 
${ }^{1} \mathrm{H} \mathrm{NMR}\left(\mathrm{CDCl}_{3}, 400 \mathrm{MHz}\right): \delta=0.89(\mathrm{t}, J=7.2 \mathrm{~Hz}, 3 \mathrm{H}), 1.21(\mathrm{t}, J=7.2$ $\mathrm{Hz}, 3 \mathrm{H}$ ), 1.28-1.39 (m, $6 \mathrm{H}$ ), 1.71 (quint, $J=7.2 \mathrm{~Hz}, 2 \mathrm{H}$ ), 2.78 (t, $J=7.2$ $\mathrm{Hz}, 2 \mathrm{H}), 3.06$ (q, J = 7.2 Hz, $2 \mathrm{H}), 6.35(\mathrm{~s}, 1 \mathrm{H})$.

${ }^{13} \mathrm{C} \mathrm{NMR}\left(\mathrm{CDCl}_{3}, 100 \mathrm{MHz}\right): \delta=7.5,14.0,22.4,26.6,27.4,28.6,31.3$, 33.1, 99.3, 161.7, 175.4, 195.6.

HRMS (TOF-Cl): $m / z\left[\mathrm{MH}^{+}\right]$calcd for $\mathrm{C}_{12} \mathrm{H}_{20} \mathrm{NO}_{2}: 210.1494$; found: 210.1495 .

\section{3-Propanoyl-5-bromomethylisoxazole (3dh)}

Pale-yellow oil; yield: $0.081 \mathrm{~g}(75 \%)$.

IR (neat): 2981, 1704, 1450, 1148, $923 \mathrm{~cm}^{-1}$.

${ }^{1} \mathrm{H} \mathrm{NMR}\left(\mathrm{CDCl}_{3}, 400 \mathrm{MHz}\right): \delta=1.22(\mathrm{t}, J=7.2 \mathrm{~Hz}, 3 \mathrm{H}), 3.08(\mathrm{q}, J=7.2$ $\mathrm{Hz}, 2 \mathrm{H}), 4.50$ (s, $2 \mathrm{H}), 6.69$ (s, $1 \mathrm{H})$.

${ }^{13} \mathrm{C}$ NMR $\left(\mathrm{CDCl}_{3}, 100 \mathrm{MHz}\right): \delta=7.4,17.9,33.2,102.3,161.8,169.0$, 194.7.

HRMS (TOF-Cl): $m / z\left[\mathrm{MH}^{+}\right]$calcd for $\mathrm{C}_{7} \mathrm{H}_{10} \mathrm{BrNO}_{2}$ : 217.9816; found: 217.9812.

\section{3-Undecanoyl-5-hexylisoxazole (3ea)}

Pale yellow oil, yield: $0.112 \mathrm{~g}$ (70\%).

IR (neat): 2925, 2857, 1703, 1454, $935 \mathrm{~cm}^{-1}$.

${ }^{1} \mathrm{H} \mathrm{NMR}\left(\mathrm{CDCl}_{3}, 400 \mathrm{MHz}\right): \delta=0.86-0.91(\mathrm{~m}, 6 \mathrm{H}), 1.26-1.38(\mathrm{~m}, 19$ H), 1.67-1.76 (m, 4 H), 2.78 (t, J = 7.6 Hz, 2 H), $3.02(\mathrm{t}, J=7.2 \mathrm{~Hz}, 2 \mathrm{H})$, $6.35(\mathrm{~s}, 1 \mathrm{H})$.

${ }^{13} \mathrm{C}$ NMR $\left(\mathrm{CDCl}_{3}, 100 \mathrm{MHz}\right): \delta=14.0,14.1,22.4,22.7,23.7,26.6,27.3$, 28.6, 29.1, 29.3, 29.3, 29.4, 29.5, 31.3, 31.9, 39.9, 99.3, 161.9, 175.4, 195.3.

HRMS (TOF-Cl): $m / z\left[\mathrm{MH}^{+}\right]$calcd for $\mathrm{C}_{16} \mathrm{H}_{35} \mathrm{NO}_{2}$ : 322.2740; found: 322.2740 .

\section{3-Undecanoyl-5-bromomethylisoxazole (3eh)}

White solid; yield: $0.115 \mathrm{~g}(70 \%) ; \mathrm{mp} 57^{\circ} \mathrm{C}$.

IR (neat): 2919, 2852, 1701, 1456, 1144, $943 \mathrm{~cm}^{-1}$.

${ }^{1} \mathrm{H} \mathrm{NMR}\left(\mathrm{CDCl}_{3}, 400 \mathrm{MHz}\right): \delta=0.88(\mathrm{t}, J=7.2 \mathrm{~Hz}, 3 \mathrm{H}), 1.22-1.38(\mathrm{~m}$, $14 \mathrm{H}$ ), 1.73 (quint, $J=7.2 \mathrm{~Hz}, 2 \mathrm{H}$ ), $3.03(\mathrm{t}, J=7.2 \mathrm{~Hz}, 2 \mathrm{H}), 4.50(\mathrm{~s}, 2 \mathrm{H})$, $6.68(\mathrm{~s}, 1 \mathrm{H})$.

${ }^{13} \mathrm{C} \mathrm{NMR}\left(\mathrm{CDCl}_{3}, 100 \mathrm{MHz}\right): \delta=14.1,17.9,22.6,23.6,29.1,29.2,29.3$, $29.4,29.5,31.8,39.9,102.3,162.0,168.9,194.3$.

HRMS (TOF-Cl): $m / z$ [MH'] calcd for $\mathrm{C}_{15} \mathrm{H}_{25} \mathrm{BrNO}_{2}$ : 330.1068; found: 330.1071

\section{3-Undecanoyl-4,5-diethoxycarbonylisoxazole (3ep)}

Pale-yellow oil; yield: $0.116 \mathrm{~g}(61 \%)$

IR (neat): 2925, 2857, 1744, 1267, 1187, 1105, $1013 \mathrm{~cm}^{-1}$.

${ }^{1} \mathrm{H} \mathrm{NMR}\left(\mathrm{CDCl}_{3}, 400 \mathrm{MHz}\right): \delta=0.88(\mathrm{t}, J=7.2 \mathrm{~Hz}, 3 \mathrm{H}), 1.26-1.34(\mathrm{~m}$, $14 \mathrm{H}), 1.39(\mathrm{t}, J=7.2 \mathrm{~Hz}, 3 \mathrm{H}), 1.40(\mathrm{t}, J=7.2 \mathrm{~Hz}, 3 \mathrm{H}), 1.69-1.77(\mathrm{~m}, 2$ $\mathrm{H}), 3.06(\mathrm{t}, J=7.2 \mathrm{~Hz}, 2 \mathrm{H}), 4.44(\mathrm{q}, J=7.2 \mathrm{~Hz}, 2 \mathrm{H}), 4.45(\mathrm{q}, J=7.2 \mathrm{~Hz}, 2$ $\mathrm{H})$.

${ }^{13} \mathrm{C} \mathrm{NMR}\left(\mathrm{CDCl}_{3}, 100 \mathrm{MHz}\right): \delta=13.9,14.0,14.1,22.7,23.3,29.0,29.3$, 29.4, 29.5, 31.9, 40.4, 62.7, 63.1, 116.9, 155.3, 158.6, 159.1, 160.3, 192.8 .

HRMS (TOF-Cl): $m / z$ [MH'] calcd for $\mathrm{C}_{20} \mathrm{H}_{32} \mathrm{NO}_{6}$ : 382.2229; found: 382.2222

\section{Conflict of Interest}

The authors declare no conflict of interest.

\section{Funding Information}

This work was supported by JSPS KAKENHI [Grant-in-Aid for Scientific Research (C) 19K05570].

\section{Supporting Information}

Supporting information for this article is available online at https://doi.org/10.1055/a-1581-0235.

\section{Primary Data}

Primary data for this article are available online at https://zenodo.org/record/5115431\#.YTWU1RIxeUl and can be cited using the following DOI: 10.5281/zenodo.5115431.

\section{References}

(1) (a) Mizuno, N.; Misono, M. Chem. Rev. 1998, 98, 199. (b) Clark, J. H. Acc. Chem. Res. 2002, 35, 791. (c) Sani, Y. M.; Daud, W. M. A. W.; Aziz, A. R. A. Appl. Catal., A 2014, 470, 140.

(2) Sato, Y.; Aoyama, T.; Takido, T.; Kodomari, M. Tetrahedron 2012, $68,7077$.

(3) Aoyama, T.; Koda, S.; Takeyoshi, Y.; Ito, T.; Takido, T.; Kodomari, M. Chem. Commun. 2013, 49, 6605.

(4) Hayakawa, M.; Aoyama, T.; Kobayashi, T.; Takido, T.; Kodomari, M. Synlett 2014, 25, 2365.

(5) Aoyama, T.; Hayakawa, M.; Kubota, S.; Ogawa, S.; Nakajima, E.; Mitsuyama, E.; Iwabuchi, T.; Kaneko, H.; Obara, R.; Takido, T.; Kodomari, M.; Ouchi, A. Synthesis 2015, 47, 2945.

(6) Aoyama, T.; Furukawa, T.; Hayakawa, M.; Takido, T.; Kodomari, M. Synlett 2015, 26, 1875.

(7) Itoh, K.; Aoyama, T.; Satoh, H.; Fuji, Y.; Sakamaki, H.; Takido, T.; Kodomari, M. Tetrahedron Lett. 2011, 52, 6892.

(8) Aoyama, T.; Itoh, K.; Furukawa, Y.; Hayakawa, M.; Shimada, S.; Ouchi, A. Synlett 2017, 28, 489.

(9) Agrawal, N.; Mishra, P. Med. Chem. Res. 2018, 27, 1309.

(10) (a) Pevarello, P.; Varasi, M. Synth. Commun. 1992, 22, 1939. (b) Heiss, J. D.; Walbridge, S.; Asthagiri, A. R.; Lonser, R. R. J. Neurosurg. 2010, 112, 790. (c) Morawska, M. M.; Fendt, M. J. Exp. Biol. 2012, 215, 1394.

(11) (a) Lauridsen, J.; Honoré, T.; Krogsgaard-Larsen, P. J. Med. Chem. 1985, 28, 668. (b) Filer, C. N.; Lacy, J. M.; Peng, C. T. Synth. Commun. 2006, 35, 967. (c) Rahim, F.; Keikhael, B.; Sarkaki, A.; Doulah, A. H. Asian. J. Anim. Vet. Adv. 2010, 5, 13.

(12) (a) Davidson, J.; Turnbull, C. J. Affect. Disord. 1983, 5, 183. (b) Larsen, J. K.; Krogh-Niesen, L.; Brøsen, K. Health Care Curr. Rev. 2016, 4, 168.

(13) (a) Davis, J. P.; Cain, G. A.; Pitts, W. J.; Magolda, R. L.; Copeland, R. A. Biochemistry 1996, 35, 1270. (b) Krisl, J. C.; Taber, D. J.; Pilch, N.; Chavin, K.; Bratton, C.; Thomas, B.; McGillicubby, J. Clin. J. Am. Soc. Nephrol. 2012, 7, 1003. (c) Chu, M.; Zhang, C. Sci. Rep. 2018, 8, 1539.

(14) (a) Ambike, A. A.; Mahadik, K. R.; Paradkar, A. Int. J. Pharm. 2004, 282, 151. (b) Gierse, J. K.; Zhang, Y.; Hood, W. F.; Walker, M. C.; Trigg, J. S.; Maziasz, T. J.; Koboldt, C. M.; Muhammad, J. L.; 
Zwifel, B. S.; Masferrer, J. L.; Isakson, P. C.; Seibert, K. J. Pharmacol. Exp. Ther. 2005, 312, 1206. (c) Szabó, G.; Fischer, J.; KisVarga, Á.; Gyires, K. J. Med. Chem. 2008, 51, 142.

(15) (a) Eicher, T.; Hauptmann, S.; Speicher, A. In The Chemistry of Heterocycles: Structures, Reactions, Synthesis, and Applications, 3rd ed; Wiley-VCH: Weinheim, Germany, 2012, 185. (b) Kiss, L.; Nonn, M.; Fülöp, F. Synthesis 2012, 44, 1951. (c) Hu, F.; Szostak, M. Adv. Synth. Catal. 2015, 357, 2583.

(16) (a) Gràcia, J.; Buli, M. A.; Castro, J.; Eichhorn, P.; Ferrer, M.; Gavaldà, A.; Hernández, B.; Segarra, V.; Lehner, M. D.; Moreno, I.; Pagès, L.; Robert, R. S.; Serrat, J.; Sevilla, S.; Taltavull, J.; Andrés, M.; Cabedo, J.; Vilella, D.; Cala, E.; Carcasona, C.; Miralpeix, M. J. Med. Chem. 2016, 59, 10479. (b) Kovács, S.; Novák, Z. Tetrahedron 2013, 69, 8987. (c) Vitale, P.; Scilimati, A. Synthesis 2013, 45, 2940.

(17) Jäger, V.; Colinas, P. A. In Synthetic Applications of 1,3-Dipolar Cycloaddition Chemistry Toward Heterocycles and Natural Products, Chap. 6; Padwa, A.; Pearson, W. H., Ed.; Wiley: Hoboken, 2003, 361.

(18) (a) Shimizu, T.; Hayashi, Y.; Teramura, K. Bull. Chem. Soc. Jpn. 1984, 57, 2531. (b) Wade, P. A.; Amin, N. V.; Yen, H.-K.; Price, D. T.; Huhn, G. F. J. Org. Chem. 1984, 49, 4595.
(19) (a) Cecchi, L.; Sarlo, F. D.; Machetti, F. Eur. J. Org. Chem. 2006, 4852. (b) Machetti, F.; Cecchi, L.; Trogu, E.; Sarlo, F. D. Eur. J. Org. Chem. 2007, 4352. (c) Trogu, E.; Cecchi, L.; Sarlo, F. D.; Guideri, L.; Ponticelli, F.; Machetti, F. Eur. J. Org. Chem. 2009, 5971. (d) Trogu, E.; Vinattieri, C.; Sarlo, F. D.; Machetti, F. Chem. Eur. J. 2012, 18, 2081.

(20) (a) Itoh, K.; Sakamaki, H.; Nakazato, N.; Horiuchi, A.; Horn, E.; Horiuchi, C. A. Synthesis 2005, 3541. (b) Nishizawa, N.; Kobiro, K.; Kiyoto, H.; Hirao, S.; Sawayama, J.; Saigo, K.; Okajima, Y.; Uehara, T.; Maki, A.; Ariga, M. Org. Biomol. Chem. 2011, 9, 2832. (c) Chen, R.; Zhao, Y.; Fang, S.; Long, W.; Sun, H.; Wan, X. Org. Lett. 2017, 19, 5896. (d) Dai, P.; Tan, X.; Luo, Q.; Yu, X.; Zhang, S.; Liu, F.; Zhang, W. Org. Lett. 2019, 21, 5096.

(21) (a) Pal, R.; Sarkar, T.; Khasnobis, S. ARKIVOC 2012, (i), 570. (b) Shrma, M.; Wanchoo, R. K.; Toor, A. P. Ind. Eng. Chem. Res. 2014, 53, 2167. (c) Kuchukulla, R. R.; Li, F.; He, Z.; Zhou, L.; Zeng, Q. Green Chem. 2019, 21, 5808.

(22) Riahi, A.; Shkoor, M.; Fatunsin, O.; Yawer, M. A.; Hussain, I.; Fischer, C.; Langer, P. Tetrahedron 2009, 65, 9300. 